natural cider yeasts, to obtain finer flavour. Artificially and naturally sweetened ciders have been compared, and apple juice has been successfully concentrated for storage purposes. The production of non-alcoholic apple juices has received considerable attention in the past year. Various combinations of dessert, culinary and cider varieties have been used for this purpose, and the effects of aeration and pasteurization studied. Seitz-filtered still juices are considered the most attractive, pasteurization having an adverse effect on flavour. As a result of the work at Long Ashton, commercial production of syrups from pure soft-fruit juices is now in operation on a large scale, and the numerous domestic uses of these products were illustrated by an exhibit of milk shakes, jellies, cake fillings, etc.

Experiments in progress on the extensive fruit plantations of the Station were open for inspection. These include investigations on the manuring of apples and soft fruits, pruning and shaping of fruit trees, rootstock trials with apples, pears and plums, and the influence of cultural treatment on the storage qualities of apples. Of particular interest on this occasion was the attempt to grow cider varieties of vintage quality as bush trees. If this can be accomplished, crops may be borne in a much shorter time than by the usual method of standard tree production. The propagation of basket and cricket bat willows also aroused considerable interest. Progress in methods of pest and disease control was illustrated by exhibits in the laboratories, a recent development being the use of cuprous oxide as a seed treatment for early peas and zinc oxide for ornamentals. The control of plum sawfly and red spider was demonstrated by the use of combined washes containing white oil emulsion and rotenonecontaining substances. In addition to horticultural research, the extensive agricultural advisory service of the Station was evident from the exhibits on dairy bacteriology, methods of pig husbandry and the economic feeding of dairy herds.

\section{The Patent Office Library}

ON May 3 Dr. Leslie Burgin, M.P. (Parliamentary Secretary of the Board of Trade), accompanied by the Comptroller-General of Patents and other officials, received a deputation from the Parliamentary Science Committee which placed before him its report on various desired improvements in accommodation and other amenities at the Patent Office. The deputation was introduced by Lieut.-Colonel Sir Arnold Wilson, M.P. Dr. Burgin expressed himself most sympathetically towards the points raised, several of which, he stated, were already being dealt with, or were in contemplation. He was precluded at present from discussing the provision of a set of duplicate search files by the adverse findings on that subject of the Sargant Committee of 1931. If, however, the Parliamentary Science Committee presented a detailed case strong enough to justify him in re-opening that subject, he would not bar and bolt the door; but the onus of justification must rest with the Committee. Dr. Burgin stated that an extension of the
Patent Office buildings was contemplated during the next few years which would allow for increased library space. On the subject of binding, he said that allocations amounting to $£ 3,100$ had been made since the Great War for the purpose of overtaking arrears, apart from substantial increases in the grant for books and binding, which had permitted of enlarged purchases of foreign publications. If the Committee would provide him with specific particulars of the foreign publications and periodicals which, in its opinion, should be added to the Library, every endeavour would be made to meet such suggestions. The deputation was satisfied that improvements in the services afforded by the Patent Office Library are in hand, and that the importance of the matters laid by them before the Board of Trade was fully appreciated by Dr. Burgin and by the officials concerned.

\section{Preservation of Monuments of Antiquity}

IN a period of economic transition such as the present, the future of many monuments of antiquity, now in private ownership, even when under the protection of the Office of Works, must continue to be precarious, owing to the breaking up of large estates. Private benefaction and public response to appeal in cases of urgent necessity have been generous in recent years ; but they cannot be expected to shoulder the burden indefinitely. The strongest safeguard for the less widely known, but often none the less important antiquities, which necessarily must run the greater risk, is a vigilant educated public opinion, backed by an enlightened authority. An example of the effective application of existing legislation in such conditions is afforded by the recent public inquiry at Worthing on a proposal to develop Highdown Hill between Worthing and Littledown as a building estate (The. Times, May 13). On account of the natural, archæological and historical interest of the site, this inquiry, held by order of the Ministry of Health, is to be regarded as of considerable importance. The Hill, a southern outlier of the South Downs, rises to a height of two hundred and sixtynine feet, and is an important feature in the maritime level tract, which is visible from far along the coast. On the summit is an earthwork, of at present uncertain age, in which was discovered in 1892 an important sixth century Anglo-Saxon cemetery. In it were eighty-six burials lying east and west in rows. The contents of the graves, of which the ornamentation suggested Frankish affinities, made this one of the most important finds of its kind in Britain. Yet the site was not scheduled under the Ancient Monuments Acts until 1930, and then only as the result of public protest, when the estate was offered for sale. The present inquiry was held on an appeal from the owner against a refusal of the Worthing Rural District Council to grant an interim development order. It was opposed by the Worthing Rural and Town Councils, the West Sussex County Council and four adjacent owners. A public-spirited offer has been made by the local authorities to accept any financial responsibility involved in the preservation of the site. 